\title{
Ethanolic extract of the Centella asiatica (L.) Urb. leaf decreases cerebellar brain-derived neurotrophic factor (BDNF) levels in rats after chronic stress
}

\author{
Dwi Cahyani Ratna Sari ${ }^{1 *}$, Desby Juananda ${ }^{2}$, Mawaddah Ar-Rochmah $^{1}$, Mansyur Romi ${ }^{1}$, \\ Nur Arfian ${ }^{1}$ \\ ${ }^{1}$ Department of Anatomy, Faculty of Medicine, Public Health adn Nursing, Universitas Gadjah Mada, \\ Yogyakarta, ${ }^{2}$ Department of Anatomy, Faculty of Medicine, Riau University, Pekanbaru, Indonesia
}

DOI: http://dx.doi.org/10.19106/JMedSci005002201801

\section{ABSTRACT}

Chronic stress produces glucocorticoid-induced neurotoxicity that may lead to alterations of the brain-derived neurotrophic factor (BDNF) concentration in the brain. Cerebellum is known to be severely affected by glucocorticoids-associated oxidative damage. Centella asiatica (L.) Urb. may protect neurons from oxidative damage. This study aimed to investigate the effect of ethanolic extract of $C$. asiatica (L.) Urb. leaf on the rat cerebellar BDNF levels following stress. Twenty young-adult male Sprague Dawley rats were randomly assigned into four experimental groups. The stress control group received aquadest, and the other groups were treated with different doses of the $C$. asiatica (L.) Urb. extract i.e 150 (CeA150), 300 (CeA300) and 600 (CeA600) mg/kg body weight/ day orally, respectively and followed by chronic footshock stress for 28 days. Upon completion of the experimental period, all animals were sacrificed and the cerebellar was isolated. The BDNF levels from the cerebellar tissue lysate was measured using ELISA. The mean BDNF levels of the cerebellar tissue in the stress control, CeA150, CeA300 and $\mathrm{CeA} 600$ groups were $1217.10 \pm 301.40 ; 771.46 \pm 241.45 ; 757.05 \pm 268.29$; and $627.00 \pm 246.02 \mathrm{pg} / \mathrm{mL}$, respectively. Post-hoc analysis showed a significant difference between the control and treatment groups $(p<0.05)$. In conclusion, the ethanolic extracts of the C. asiatica (L.) Urb. leaf decrease the cerebellar BDNF levels in rats after chronic stress.

\section{ABSTRAK}

Stress kronis menyebabkan terjadinya sekresi glukokortikoid sehingga menginduksi terjadinya neurotoksisitas dan memicu terjadinya perubahan konsentrasi brain-derived neurotrophic factor (BDNF) pada otak. Cerebellum sangat dipengaruhi oleh glukokortikoid yang berhubungan dengan stres oksidatif. Centella asiatica (L.) Urb. dikenal dapat melindungi neuron dari kerusakan akibat stres oksidatif. Tujuan penelitian ini adalah mengkaji pengaruh $C$. asiatica (L.) Urb. terhadap konsentrasi BDNF di cerebellum pada kondisi stres. Dua puluh tikus jantan Sprague Dawley dibagi menjadi 4 kelompok perlakuan, yaitu kontrol, ekstrak C. asiatica (L.) Urb. 150 (CeA150), 300 (CeA300), 600 (CeA600) $\mathrm{mg} / \mathrm{kg}$ berat badan/hari dan diikuti oleh pemberian stress kronik (footshock stress) selama 28 hari berturut-turut. Diakhir perlakuan, semua hewan coba diterminasi

\footnotetext{
* corresponding author: dwi.cahyani@ugm.ac.id
} 
dan dilakukan isolasi protein dari cerebellum. Konsentrasi BDNF dari cerebellum diukur dengan menggunakan metode ELISA. Rerata konsentrasi BDNF untuk kelompok kontrol, CeA150, CeA300, CeA600, berturut-turut adalah 1217,10 $\pm 301,40 ; 771,46 \pm 241,45$; $757,05 \pm 268,29$ dan $627,00 \pm 246,02 \mathrm{pg} / \mathrm{mL}$. Hasil uji analisis post-hoc menunjukkan terdapat perbedaan yang signifikan antara kelompok kontrol dan perlakuan $(p<0,05)$. Dapat disimpuakan, ekstrak etanol C. asiatica (L.) Urb. menurunkan konsentrasi BDNF pada cerebellum tikus setelah diinduksi stres kronis.

Keywords: BDNF - Centella asiatica (L.) Urb. - cerebellum - chronic stress - prevention

\section{INTRODUCTION}

Centella asiatica (L.). Urb. or 'Gotu Kola' is a tropical medicinal herb plant that flourishes in swampy areas of Asian countries. The primary active constituents of $C$. asiatica (L.) Urb that have important medicinal applications are triterpenoids and flavonoids. ${ }^{1}$ These triterpenes which include asiatic acid and asiaticoside, exert a significant neuroprotective effect on the rat brain against oxidative damage ${ }^{2}$ due to their high antioxidant activity and the reduction of the permeability of the blood-brain barrier. ${ }^{3}$ Previous studies showed that the administration of ethanol extracts of C. asiatica (L.) Urb. in rats following chronic stress affects the concentration of serum and hippocampal brain-derived neurotrophic factor (BDNF), which is an endogenous neuroprotective agent in the brain..$^{4-6}$ The brain is the central organ for stress adaptation and is also a target of stress. ${ }^{6}$ Chronic stress may result in abnormal changes in brain plasticity, including dendritic retraction, neuronal toxicity and suppression of neurogenesis, as well as axospinous synaptic plasticity. ${ }^{7}$ Repetitive stress exposure will gradually change the electrical characteristic, morphology, and proliferative capacity of neurons. ${ }^{8}$ Several studies on animals have examined the involvement of the oxidative status in the adaptive response of the animals to stress. Physical or psychological stressors cause oxidative damage by inducing an imbalance between the pro-oxidant and antioxidant status. ${ }^{9}$

Of the brain regions, the cerebellum is known to be severely affected by oxidative damage associated with glucocorticoid levels due to high levels of glucocorticoid receptors localized in the external granular layer. ${ }^{10}$ Several reasons might contribute to its high vulnerability: the large quantity of oxidizable lipids; high iron content; and relatively low level of antioxidant defense molecules, mainly glutathione and vitamin E. ${ }^{11}$ A robust increase in basal cerebellar oxidative stress causes abnormal changes, such as poor dendritic arborization of Purkinje cells, alterations of the cellular organelles and neuronal death. ${ }^{12}$ Chronic stress has been shown to downregulate the glucocorticoid receptors of mRNA in the granular and Purkinje cell layers. ${ }^{13}$

BDNF, a member of the neurotrophin family, is known to be a strong survival promoting factor and plays a critical role in cell proliferation and differentiation, neuronal protection, and regulation of synaptic functioning in the central nervous system. ${ }^{14}$ BDNF is highly expressed in the cerebellum, mainly in granular cells. Both granular and Purkinje cells express the BDNF receptor tropomyosin-receptor kinase B (TrkB).${ }^{15}$ Gene deletion of mouse BDNF increases granular cell death, stunts the growth of Purkinje cell dendrites, and impairs the foliation patterns. Previous studies have shown that BDNF can 
also protect neurons from injuries caused by hypoglycemia, ischemia, hypoxia and neurotoxicity. ${ }^{16}$

Acute and chronic stress alter the expression of BDNF and TrkB in the brain. ${ }^{17}$ Some studies have shown that chronic stress decreased BDNF mRNA and protein expression in the hippocampus, but acute stress has the opposite effect. ${ }^{18}$ In contrast, chronic multiple stress has been shown to induce a significant increase in BDNF and TrkB protein expression in the hippocampus. ${ }^{19}$ The up/down-regulation of BDNF is affected by the type of stressors, the intensity, the duration, and the number of exposures. ${ }^{20}$

Although the impact of stress on the BDNF levels displayed different results, BDNF is believed to protect neurons from injuries caused by stress. However, previous clinical trials have reported that BDNF had poor penetration through the blood brain barrier, making it very difficult to use as a drug. ${ }^{21}$ Therefore, we investigated the neuroprotective effect of ethanolic extract of C. asiatica (L.) Urb. leaf on the cerebellar tissue BDNF levels in chronically stressed rats.

\section{MATERIALS AND METHODS}

\section{Animals}

Twenty young-adult ( 8 weeks) male Sprague Dawley rats weighing 100-150 g were obtained from the Animal Model Care Unit, Universitas Gadjah Mada, Yogyakarta, Indonesia and were housed under standard laboratory conditions (at $25-30^{\circ} \mathrm{C} ; 50 \%-60 \%$ humidity; with $12 \mathrm{~h}$ light and dark cycles). All animals were given access to the diet and tap water ad libitum. The rats were placed in glass cages, with two animals per cage, and were allowed to acclimatize one week prior to treatment.
The animals were randomly assigned into four experimental groups, with five rats per group: the stress control, CeA150, CeA300 and CeA600 groups. The control group received aquadest alone, and the other groups were treated with different doses ( $\mathrm{mg} / \mathrm{kg} \mathrm{BW} /$ day, p.o.) of $C$. asiatica (L.) Urb. leaf ethanolic extracts: 150 (CeA150), 300 (CeA300) and 600 (CeA600), followed by chronic footshock stress for 28 days. All experimental procedures were approved by the Medical and Health Research Ethics Committee, Faculty of Medicine, Gadjah Mada University (Ref. $\mathrm{KE} / \mathrm{FK} / 657 / \mathrm{EC})$.

\section{Administration of ethanolic extracts of $C$. asiatica (L.) Urb.}

The fresh leaves of $C$. asiatica (L.). Urb. were procured from the commercial herb manufacturer (Merapi Farma Herbal, Sleman, Yogyakarta), and samples of the plant were identified and authenticated for their correct botanical identity at the Faculty of Biology, Universitas Gadjah Mada. Ethanolic extracts of C. asiatica (L.) Urb. were obtained using maceration methods from the Integrated Testing and Research Labortory, Universitas Gadjah Mada. The leaves were cleaned, airdried, and made into powder. The powder was soaked in a $70 \%$ ethanol solution in a shaking incubator for 2 days. The extracted solution was filtered through filter paper and concentrated. The concentrate was evaporated through a vacuum rotary evaporator at $70^{\circ} \mathrm{C}$ followed by a water bath. The filtrate from this process was weighed and dissolved in a sterile aquadest to create the various dose-dependent preparations $(150,300$, and $600 \mathrm{mg} / \mathrm{kg} \mathrm{BW})$. The ethanolic extracts of the C. asiatica (L.) Urb. leaf were administered orally using an oral gastric tube for 28 consecutive days with weekly weight-adjusted doses. 


\section{Stress induced procedure}

Thirty min after the oral administration of C. asiatica, (L.) Urb. each rat was subjected to footshock stress using a plexiglass rodent shock box. The plexiglass rodent shock box consisted of a box containing an animal space which is positioned on a metallic grid floor connected to a shock generator. Each rat was placed in the box and received $10 \mathrm{~min} /$ day inescapable footshock stress (a footshock of $0.8 \mathrm{~mA} / 50 \mathrm{~V}$ in intensity and $10 \mathrm{~s}$ in duration with a 15-s interval). Footshock stress was given chronically for 28 consecutive days.

\section{Fecal pellets procedure}

The fecal pellets were quantified after the rats got electrical stress. The fecal pellets were directly collected after the rats underwent electrical stress in the plexiglass rodent shock box. Each fecal pellets was collected with a small forcep and counted it manually.

\section{Cerebellar tissue collection}

Upon completion of the experimental period, the animals were decapitated according to the Institutional Animal Care and Use Committee (IACUC) instructions. Brain tissue was dissected immediately over an ice pack, and the cerebellar tissue was separated manually from the other brain region. Cerebellar tissue was then stored in safe lock tubes at $-80^{\circ} \mathrm{C}$ until they were used for immunoblotting and ELISA. For immunohistochemistry (IHC) study, the animals were perfused with normal saline. After that the brains were quickly removed and stored in 4\% paraformaldehyde fixative solution.

\section{Immunohistochemistry procedure}

Before proceeding to the staining protocol, the tissue sections were deparaffinized and rehydrated with xylene and alcohol. Endogenous peroxidase was blocked by preincubating the tissue sections in $0.3 \% \mathrm{H}_{2} \mathrm{O}_{2}$ with methanol. Antigen retrieval was done by heating the slides in a sodium citrate buffer. Finally, immunohistochemistry staining was processed with an HRP universal detection kit (Starr Trek from Biocare Medical ${ }^{\circledR}$; Cat. No. STUHRP700 H, L10). Inappropriate protein was blocked by a background sniper (protein blocker), and we applied the rat BDNF-antibody (Abcam ${ }^{\circledR}$; Cat. No. ab80436) overnight. The tissue sections were washed with PBS buffer and then incubated with secondary antibody. The HRP conjugate was applied, and subsequently, the tissue sections were incubated in betazoid DAB chromogen. The counter stain solution (hematoxyllin Meyer) was applied, and the dehydrated tissue with alcohol and xylene was mounted/ coverslipped.

\section{The extraction of cerebellar tissue protein}

Protein from the cerebellar tissue was extracted using the Pro-Prep ${ }^{\mathrm{TM}}$ (Intron Biotechnology; Cat. No. 17081) protein extraction solution according to the manufacturer's instructions. Twenty $\mathrm{mg}$ of cerebellar tissue were mashed and homogenized with approximately $600 \mu \mathrm{L}$ of Pro-Prep ${ }^{\mathrm{TM}}$ solution. The homogenates were incubated for $30 \mathrm{~min}$ at $-20^{\circ} \mathrm{C}$ and were centrifuged at $12,000 \mathrm{rpm}$ at $4^{\circ} \mathrm{C}$ for $5 \mathrm{~min}$. The supernatants were stored in safe lock tubes at $-80^{\circ} \mathrm{C}$ until they were assayed.

\section{The measurement of cerebellar tissue BDNF concentrations}

The cerebellar tissue BDNF levels were measured using a Rat BDNF enzyme-linked immunosorbent assay (ELISA) kit (Boster Immunoleader; Cat. No. EK0308) according 
Dwi Cahyani Ratna Sari et al., Ethanolic extract of the Centella asiatica (L.) Urb. leaf decreases cerebellar brain-derived neurotrophic factor (BDNF) levels in rats after chronic stress

to the manufacturer's instructions. A standard curve ranging from 31.2 to $2000 \mathrm{pg} / \mathrm{mL}$ of BDNF was obtained by the absorbance at 450 $\mathrm{nm}$. This curve was used to create a formula to determine the BDNF levels from the optical density.

\section{Statistical analysis}

The data are presented as the mean \pm standard deviation (SD). Differences among groups were calculated by the parametric oneway ANOVA test using SPSS v 16.0 software. Post hoc analysis was conducted to determine differences between each group. A p value of less than 0.05 were considered statistically significant.

\section{RESULTS}

\section{Body weight rats}

Comparisons of the mean body weights before and after the stress induction for all of the groups are presented in TABLE 1. A significant difference in the mean body weight before and after the stress induction was observed $(\mathrm{p}<0.05)$ indicating that the chronic footshock stress significantly increased body weight for all of the groups.

TABLE 1. The body weights (mean \pm SD g) before and after the stress procedures

\begin{tabular}{ccccc}
\hline Group & $\mathbf{n}$ & Before stress induction & After stress induction & $\mathbf{p}$ \\
\hline Control & 5 & $158 \pm 25.88$ & $192 \pm 17.88$ & 0.042 \\
CeA150 & 5 & $140 \pm 7.07$ & $192 \pm 8.36$ & 0.034 \\
CeA300 & 5 & $184 \pm 15.16$ & $220 \pm 24.49$ & 0.042 \\
\hline CeA600 & 5 & $176 \pm 8.94$ & $206 \pm 13.41$ & 0.039 \\
\hline
\end{tabular}

\section{Fecal pellet}

The means of the fecal pellets during the stress induction are presented in TABLE 2. The data show that chronic footshock stress induced defecation reflexes in all groups. The group with the most fecal pellets was the CeA300 group (5.8 \pm 1.08 units), and the group with the least fecal pellets was the Control group (4.32 \pm 0.77 units).

TABLE 2. The fecal pellet production during the stress induction

\begin{tabular}{lcc}
\hline \multicolumn{1}{c}{ Group } & n & $\begin{array}{c}\text { Fecal pellet } \\
\text { (mean } \pm \text { SD units) }\end{array}$ \\
\hline Control & 5 & $4.32 \pm 0.77$ \\
CeA150 & 5 & $4.87 \pm 0.36$ \\
CeA300 & 5 & $5.80 \pm 1.08$ \\
CeA600 & 5 & $5.15 \pm 0.66$ \\
\hline
\end{tabular}

\section{Cerebellar tissue BDNF immunohistochemistry examination}

BDNF protein was expressed in the granular, Purkinje, and molecular cell layers of the cerebellar cortex hemisphere (FIGURE 1). Chronic footshock stress increased the cerebellar tissue protein expression in rats demonstrated the higher BDNF protein expression in the control group (B) compared to that the negative control/non-stressed rat (A). The administration of ethanolic extract of C. asiatica (L.) Urb. leaf in CeA150 (C), CeA300 (D) and CeA600 (E) followed by chronic footshock stress decreased cerebellar tissue BDNF expression. 

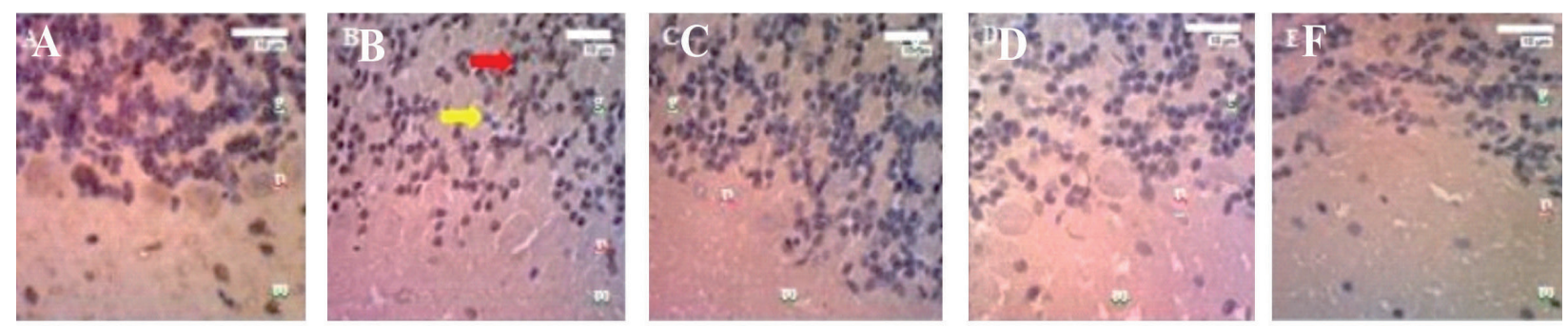

FIGURE 1. Tissues were stained with rat BDNF-antibody (Abcam $(\mathbb{R})$ N No. Cat. Ab80436), and observed under a light microscope with a 10x magnification level. (A) negative control group (non-stressed rat); (B) Control stress group (aquadest); (C) CeA150; (D) CeA300; (D) CeA600; (g) granular cell layer; (p) Purkinje cell layer; (m) molecular cell layer; Red mark displayed BDNF expression; Yellow mark did not display BDNF expression.

\section{Cerebellar tissue BDNF levels}

The mean cerebellar tissue BDNF levels for all groups are presented in FIGURE 2. A significant difference of mean cerebellar tissue BDNF levels between groups was observed $(p<0.05)$. Furthermore, the cerebellar tissue BDNF levels were significantly lower after ethanolic extract of C. asiatica (L.) Urb. treatment (groups CeA150, CeA300, and CeA600) compared to that the control group $(\mathrm{p}<0.05)$. However, the cerebellar tissue BDNF levels were not significantly different between the dose of ethanoic extract of $C$. asiatica (L.) Urb. treatment groups ( $\mathrm{p}>0.05)$.

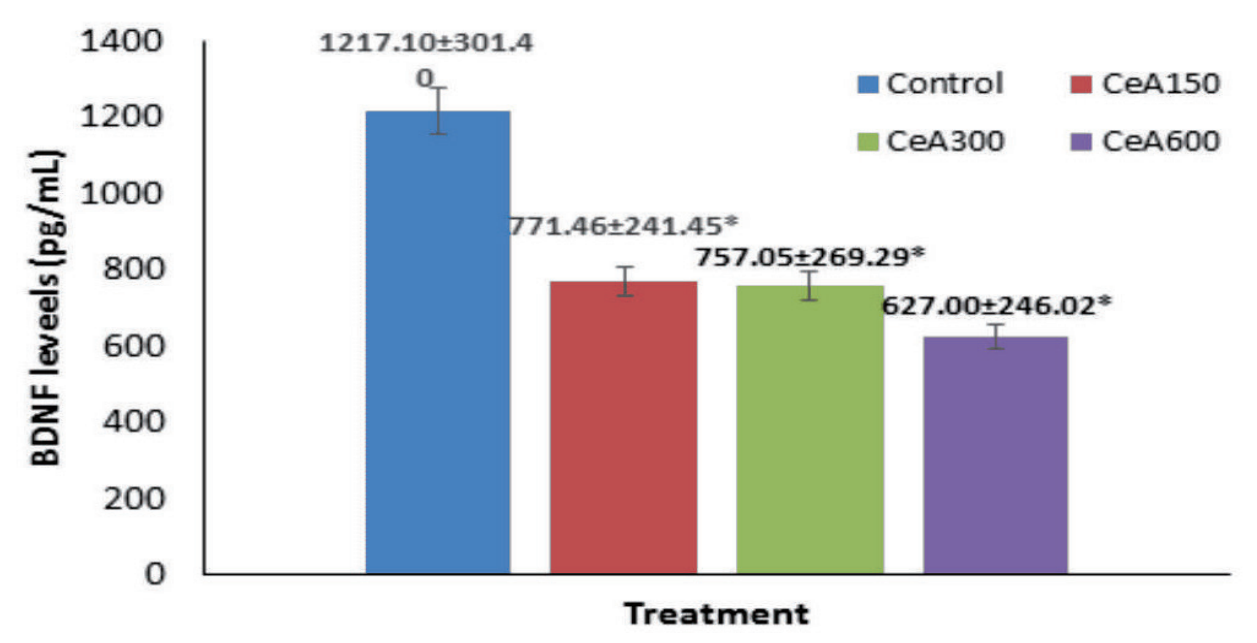

FIGURE 2. Rats cerebellar tissue BDNF levels after the administration of ethanolic extract of $C$. asiatica leaf followed by chronic footshock stress. *significantly different compared to control $(p<0.05)$.

\section{DISCUSSION}

In this study, we assumed that the chronic footshock stress procedure caused functional changes in rats, such as increased body weight and induced defecation. We also assumed that the brain, especially the cerebellum, responded to this chronic stress procedure through structural and chemical changes. Prolonged or 
extreme stressors induce abnormal changes in brain plasticity that, paradoxically, impair the ability of the brain to regulate and respond to subsequent stressors. ${ }^{8}$

Both acute and chronic stress can influence eating patterns. The severity of the stressor seems to influence food intake in the rat model. Chronic stress may increase food intake and body weight when the foods offered are highly palatable (high-fat diet). ${ }^{22}$ This phenomenon is believed to be due to a greater preference for energy and nutrient dense food during and after stressors. Increased ingestion of palatable food may reflect a pleasing activity that reduces the discomfort of stress. ${ }^{23}$ Chronic stress induces the activation of the HPA axis and may stimulate orexigenic neuropeptides, including neuropeptide-Y (NPY) and agouti related peptide (AgRP) ${ }^{24}$ On the other hand, glucocorticoids may inhibit the release of an anorexigenic hormone, such as the corticotropin-releasing hormone $(\mathrm{CRH})$, and cause hyperphagia. ${ }^{23,24}$

The gastrointestinal tract is particularly sensitive to stress. Both acute and chronic stress induce colon mucosal hyper responsiveness. ${ }^{25}$ Previous studies showed that central CRH signaling mediates gastrointestinal responses to stress. ${ }^{26}$ Chronic stress exposure has been proven to increase colon motility and induce the defecation reflex. ${ }^{27}$ It is also believed to be due to the release of peripheral 5-HT mediated by CRH. A previous study showed that the administration of a 5-HT3 receptor antagonist inhibited CRH-induced defecation in a dosedependent manner. ${ }^{28}$ This finding has clinical relevance for symptoms of irritable bowel syndrome (IBS) caused by the activation of CRH pathways. ${ }^{26}$

In this study, chronic footshock stress might increase the cerebellar tissue BDNF leves in rats, which has been demonstrated through the immunohistochemistry staining of the cerebellar cortex layers with a rat BDNF-antibody (FIGURE 1). The rat BDNF protein expression in the stress control group was higher than that in the negative control group (non-stressed rats). A previous study reported that early postnatal repeated maternal deprivation caused a transient increase in rat BDNF mRNA and protein levels. ${ }^{29}$ In contrast, some studies have shown that chronic stress decreased rat BDNF mRNA and protein expression in some brain areas. ${ }^{30,31}$ These results prove that stress has an important role in BDNF regulation.

There are some possible explanations for the different results in this study. First, the increase of cerebellar BDNF levels in response to chronic stress may be due to the sex, strain, and age of the rat at the time of stress exposure. Previous studies reported that the cerebellum is more sensitive to stress four to nine days after birth. ${ }^{32}$

Second, it is possible that the discrepancy in the effect of chronic stress is due to differences in the stress protocols applied in the different studies. The effect of stress on cerebellar BDNF expression in the cerebellum appears to be dependent on several factors, such as the type of stressor, the intensity, the duration, the frequency and the number of exposures. ${ }^{20}$ Increases in the cerebellar BDNF levels are believed to be due to alterations of the glucocorticoid receptor activity induced by stress. Both mineralocorticoid (MR) and glucocorticoid receptors (GR) mediate the bidirectional action of neuronal cells in response to stress. ${ }^{33}$

Third, although speculative, it is possible that exposure to chronic stress activates mechanisms in the cerebellum that reflect an adaptive protective response. ${ }^{20}$ The upregulation of the cerebellar BDNF levels induced by stress may be a compensatory adaptation to repeated stress. BDNF has 
been reported to protect neurons from oxidative damage caused by stress. ${ }^{14}$ The anti-apoptosis activity of BDNF is considered to be the underlying mechanism behind the neuroprotective effect of this protein. BDNF may reduce neuron apoptosis by increasing the expression of the Bcl-2 anti-apoptosis protein and inhibiting intracellular calcium

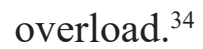

BDNF increases glucose transport by inducing the expression of GLUT3 and also increases $\mathrm{Na}^{+}$- dependent amino acid transport and protein synthesis. ${ }^{35}$ BDNF up-regulates antioxidant enzymes and enhances the repair of damaged DNA in neurons. This study also suggests that the up-regulation of cerebellar BDNF levels could be induced by the stressinduced specific activation of some BDNF gene promoters in cerebellar macrophages or in neurons. The dopaminergic neurons that sprout as a result of stress appear to activate macrophage BDNF secretion. ${ }^{36}$

In this study, the administration of ethanolic extract of $C$. asiatica (L.) Urb. leaf ethanol extracts followed by chronic footshock stress significantly decreased the cerebellar tissue BDNF levels of rats in all groups. The decrease of the cerebellar tissue BDNF level is believed to be due to the down-regulation process of neurons and glia in response to the neuroprotective effect of ethanolic extract of C. asiatica (L.) Urb. It is still possible that the neuroprotective effect of ethanolic extract of C. asiatica leaf (L.) Urb. is mediated by other neurotrophic factors, such as neural growth factor (NGF), basic fibroblast growth factor (bFGF), glial-derived neurotrophic factor (GDNF), neurotrophin-3 (NT-3), and NT-4/5. It was reported that the major chemical compounds in C. asiatica (L.) Urb., including asiatic acid, madecassic acid, asiaticoside, madecassoside and madasiatic acid, play an important role in neuroprotective activity. ${ }^{37}$ It is believed to be due to its high anti-oxidant and anti-apoptosis activity, which is mediated by decreasing the blood-brain barrier permeability. ${ }^{3}$

Administrations of ethanolic etract of $C$. asiatica (L.) Urb. prevent lipid peroxidation and limit the protein carbonyl content in the rat brain region. ${ }^{38}$ The extract is also able to protect neuron cells from oxidative stress by inhibiting the activation of the caspase- 9 pathway. The anxiolytic, antidepressant and anti-stress effects of $C$. asiatica (L.) Urb. may alter glucocorticoid activities and the adaptation response to stress. ${ }^{38-41}$ Although a speculation, the reciprocal relationship between the cerebellum and HPA-axis was recently established by the discovery of dense glucocorticoids binding sites on the vermis. ${ }^{42}$ In this study, we added biochemical evidence that $C$. asiatica (L.) Urb. has a role as a neuroprotective agent in the brain, mainly in the cerebellum.

\section{CONCLUSION}

In conclusion, the administration of ethanolic extract of $C$. asiatica (L.) Urb. leaf decreases the cerebellar tissue BDNF protein levels in rats after chronic stress. The BDNF protein is expressed in the Purkinje, granular, and molecular cell layers of the cerebellar cortex. It would be interesting to examine possible contributions from other neurotrophic factors, such as NGF, bFGF, GDNF, NT3 or NT-4/5.

\section{ACKNOWLEDGEMENTS}

The authors would like to thank Dr. dr. Djoko Prakosa, PA(K), Prof. dr. Soedjono Aswin, PhD and dr. Rina Susilowati, PhD for their suggestions during the completion of this study. We also thank Mr. Mulyana for all of his 
help as the Laboratory Assistant and dr. Hayu Qaimamunazzala for English language editing. This study was funded by the Annual Medical Faculty Gadjah Mada University Research Grant for the BDNF level measurements and the University Leading Research Grant (Penelitian Unggulan Perguruan Tinggi).

\section{REFERENCES}

1. Gohil KJ, Patel JA, Gajjar AK. Pharmacological review on centella asiatica: a potential herbal cure-all. Indian J Pharm Sci 2010; 72(5):546-56. http://dx.doi.org/10.4103/0250-474X.78519

2. Seevaratnam V, Banumathi $P$, Premalatha $\mathrm{M}$, Sundaram S, Arumugam T. Functional Properties of Centella asiatica (L.): a review. Int J Pharm Pharm Sci 2012; 4(Suppl 5):8-14

3. Krishnamurthy RG, Senut MC, Zemke D, Min J, Frenkel MB, Greenberg EJ, et al. Asiatic acid, a pentacyclic triterpene from Centella asiatica, is neuroprotective in a mouse model of focal cerebral ischemia. J Neurosci Res 2009; 87(11):2541-50. http://dx.doi.org/ 10.1002/jnr.22071.

4. Sari DCR, Aswin S, Susilowati R, Arrochmah M, Prakosa D, Tranggono U, et al. Ethanol extracts of Centella asiatica leaf improves memory performance in rats after chronic stress via reducing nitric oxide and increasing brain-derived neurotrophic factor (BDNF) concentration. Int J Psychol 2014; 1(1):61-7. http://dx.doi.org/10.7603/s40790-014-00090 .

5. Sari, D. \& Ar Rochmah, M. The effects of ethanol extracts of Centella asiatica Leaf on serial serum brain derived neurotrophin factor (BDNF) concentration of rats (Sprague Dawley) Following Chronic Stress. KnE Life Sci 2015; 2:159-67. http://10.18502/kls.v2i1.136
6. Sari, D. C. R. Efek neurotrofik dan neuroprotektif ekstrak ethanol daun pegagan (Centella asiatica (L.) Urb.) terhadap gangguan memori spasial pasca-stres kronik. [Tesis]. Yogyakarta: Universitas Gadjah Mada, 2015.

7. Popoli M, Yan Z, Mcewen BS, Sanacora G. The stressed synapse: the impact of stress and glucocorticoids on glutamate transmission. Nat Rev Neurosci 2011; 13(1):22-37. http:// dx.doi.org/10.1038/nrn3138.

8. Radley JJ, Morrison JH. Repeated stress and structural plasticity in the brain. Ageing Res Rev 2005; 4(2):271-87. http://dx.doi.org/10.1016/j.arr.2005.03.004.

9. Joels M, Karst H, Krugers HJ, Lucassen PJ. Chronic stress: implications for neuronal morphology, function and neurogenesis. Front Neuroendocrinol 2007; 28(2-3):72-96. http://dx.doi.org/10.1016/j.yfrne.2007.04.001

10. Zafir A, Banu N. Modulation of in vivo oxidative status by exogenous corticosterone and restraint stress in rats. Stress 2009; 12(2):167-77.

h t t p://dx.doi.org/10.1080/ 10253890802234168.

11. Biran V, Verney C, Ferriero DM. Perinatal cerebellar injury in human and animal models. Neurol Res Int 2012. 858929. http://dx.doi.org/10.1155/2012/858929.

12 Assunção M, Santos-marques MJ, de Freitas V, Paula-barbosa MM, Carvalho F. Modulation of rat cerebellum oxidative status by prolonged red wine consumption. Addict Biol 2008; 13(3-4):337-44.

http://dx.doi.org/10.1111/j.13691600.2008.00103.x

13. Kitraki E, Karandrea D, Kittas C. Longlasting effects of stress on glucocorticoid receptor gene expression in the rat brain. Neuroendocrinology 1999; 69(5):331-8. http://dx.doi.org/10.1159/000054435

14. Numakawa $T$, Matsumoto $T$, Numakawa Y, Richards M, Yamawaki S, Kunugi H. 
Protective action of neurotrophic factors and estrogen against oxidative stress-mediated neurodegeneration. J Toxicol 2011; 405194. http://dx.doi.org/10.1155/ 2011/405194.

15. Schwartz PM, Borghesani PR, Levy RL, Pomeroy SL, Segal RA. Abnormal cerebellar development and foliation in BDNF -/- mice reveals a role for neurotrophins in CNS patterning. Neuron 1997; 19(2):269-81.

http://dx.doi.org/10.1016/S08966273(00)80938-1.

16. Sun X, Zhou H, Luo X, Li S, Yu D, Hua J, et al. Neuroprotection of brain-derived neurotrophic factor against hypoxic injury in vitro requires activation of extracellular signal-regulated kinase and phosphatidylinositol 3-kinase. Int J Devl Neurosci 2008; 26(3-4):363-70.

http://dx.doi.org/10.1016/j. ijdevneu.2007.11.005.

17. Suri D, Vaidya VA. Glucocorticoid regulation of brain-derived neurotrophic factor: relevance to hippocampal structural and functional plasticity. Neuroscience 2012; 239:196-213.

ht tp://dx.doi.org/10.1016/j . neuroscience.2012.08.065

18. Shi SS, Shao SH, Yuan BP, Pan F, Li ZL. Acute stress and chronic stress change brain-derived neurotrophic factor (BDNF) and tyrosine kinase-coupled receptor (TrkB) expression in both young and aged rat hippocampus. Yonsei Med J 2010; 51(5):661-71. http://dx.doi.org/10.3349/ymj.2010.51.5.661.

19. Li XH, Liu NB, Zhang MH, Zhou YL, Liao JW, Liu XQ, et al. Effects of chronic multiple stress on learning and memory and the expression of Fyn, BDNF, TrkB in the hippocampus of rats. Chin Med J (Engl) 2007; 120(8):669-74.

20. Larsen MH, Mikkelsen JD, Hay-schmidt A, Sandi C. Regulation of brain-derived neurotrophic factor (BDNF) in the chronic unpredictable stress rat model and the effects of chronic antidepressant treatment. J Psychiatr Res 2010; 44(13):808-16.

h t tp://dx.doi.org/10.1016/j. jpsychires.2010.01.005.

21. Allen SJ, Dawbarn D. Clinical relevance of the neurotrophins and their receptors. Clin Sci (lond) 2006; 110(2):175-91. http://dx.doi.org/10.1042/CS20050161.

22. Torres SJ, Nowson CA. Relationship between stress, eating behavior, and obesity. Nutrition 2007; 23(11-12):887-94. http://dx.doi.org/10.1016/j.nut.2007.08.008.

23. Bazhan N, Zelena D. Food-intake regulation during stress by the hypothalamo-pituitaryadrenal axis. Brain Res Bull; 2013; 95:46-53. ht tp://dx.doi.org/10.1016/ j.brainresbull.2013.04.002.

24. Maniam J, Morris MJ. Neuropharmacology the link between stress and feeding behaviour. Neuropharmacology 2012; 63(1):97-110.

h t t p://dx.doi.org/10.1016/ j.neuropharm.2012.04.017.

25. Mayer EA, Naliboff BD, Chang L, Coutinho SV. V. stress and irritable bowel syndrome. Am J Physiol Gastrointest Liver Physiol 2001; 280(4):519-24.

h t t p : //dx.doi.org/10.1152/ ajpgi.2001.280.4.G519

26. TachéY,BonazB. Review series corticotropinreleasing factor receptors and stress-related alterations of gut motor function. J Clin Invest 2007; 117(1):33-40. http://dx.doi.org/10.1172/JCI30085.

27. Miyata $\mathrm{K}$, Ito $\mathrm{H}$, Fukudo S. Involvement of the 5-HT3 receptor in CRH-induce defecation in rats. Am J Physiol 1998; 274(5 Pt 1):82731.

28. Sanger GJ, Yoshida M, Yahyah M, Kitazumi $\mathrm{K}$. Increased defecation during stress or after 5-hydroxytryptophan: selective inhibition by the 5-HT 4 receptor antagonist, SB-207266. Br J Pharmacol 2000; 130(3):706-12. http://dx.doi.org/10.1038/sj.bjp.0703367. 
29. Miki T, Yokoyama T, Kusaka T, Suzuki S, Ohta K, Warita K, et al. Early postnatal repeated maternal deprivation causes a transient increase in OMpg and BDNF in rat cerebellum suggesting precocious myelination. J Neurol Sci 2014; 336(1-2):627. http://dx.doi.org/10.1016/j.jns.2013.10.007.

30. Banerjee R, Ghosh AK, Ghosh B, Mondal AC. Effect of chronic inescapable footshock and antidepressant treatment on BDNF/TrkB levels in rat hippocampus. J Neurosci 2012; 2(2):12-21.

31. Grønli J, Bramham C, Murison R, Kanhema T, Fiske E, Bjorvatn B, et al. Chronic mild stress inhibits BDNF protein expression and CREB activation in the dentate gyrus but not in the hippocampus proper. Pharmacol Biochem Behav 2006; 85(4):842-9. http://dx.doi.org/10.1016/j.pbb.2006.11.021.

32. Kumar A, LaVoie HA, Dipette DJ, Singh US. Ethanol neurotoxicity in the developing cerebellum: underlying mechanisms and implications. Brain Sci 2013; 3(2):941-63. http://dx.doi.org/10.3390/brainsci3020941.

33. de Kloet ER, Joëls M, Holsboer F. Stress and the brain: from adaptation to disease. Nat Rev Neurosci 2005; 6(6):463-75. http://dx.doi.org/10.1038/nrn1683.

34. Chen A, Xiong LJ, Tong Y, Mao M. The neuroprotective roles of BDNF in hypoxic ischemic brain injury. Biomed Rep 2013; 1(2):167-76. http://dx.doi.org/ 10.3892/br.2012.48

35. Marosi K, Mattson MP. BDNF mediates adaptive brain and body responses to energetic challenges. Trends Endocrinol Metab 2013; 25(2):89-98. http://dx.doi.org/10.1016/j.tem.2013.10.006

36. Batchelor PE, Liberatore GT, Wong JYF, Porritt MJ, Frerichs F, Donnan GA, et al.
Activated macrophages and microglia induce dopaminergic sprouting in the injured striatum and express brain-derived neurotrophic factor and glial cell line-derived neurotrophic factor. J Neurosci 1999; 19(5):1708-16.

ht tps://doi.org/10.1523/ JNEUROSCI.19-05-01708.1999

37. Orhan IE. Centella asiatica ( L .) urban: from traditional medicine to modern medicine with neuroprotective potential. J Evid Based Complementary Altern Med 2012; 946259. http://dx.doi.org/10.1155/2012/946259.

38. Subathra M, Shila S, Devi MA, Panneerselvam C. Emerging role of Centella asiatica in improving age-related neurological antioxidant status. Exp Gerontol 2005; 40(89):707-15.

http://dx.doi.org/10.1016/j. exger.2005.06.001.

39. Liang X, Huang YN, Chen SW, Wang WJ, $\mathrm{Xu}$ N, Cui S, et al. Antidepressant-like effect of asiaticoside in mice. Pharmacol Biochem Behav 2008; 89(3):444-9. http://dx.doi.org/10.1016/j.pbb.2008.01.020.

40. Hemamalini, M. S. R. Anti stress effect of Centella asiatica leaf extract on hippocampal CA3 neurons - a quantitative study. Int $\mathrm{J}$ Pharmacoland Clin Sci 2013; 2(1):25-32.

41. Wijeweera P, Arnason JT, Koszycki D, Merali Z. Evaluation of anxiolytic properties of gotukola--(Centella asiatica) extracts and asiaticoside in rat behavioral models. Phytomedicine 2006; 13(9-10):668-76.

h t t p://dx.doi.org/10.1016/ j.phymed.2006.01.011.

42. Schutter DJ, van Honk J. The cerebellum on the rise in human emotion. Cerebellum 2005; 4(4):290-4.

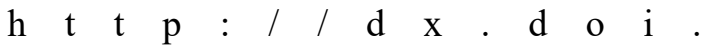
org/10.1080/14734220500348584 